\title{
Justice in Urban Climate Change Adaptation: Criteria and Application to Delhi
}

\author{
Sara Hughes ${ }^{1}$
}

\begin{abstract}
Cities around the world are increasingly developing plans to adapt to the consequences of climate change. These plans will have important consequences for urban populations because they are likely to reshape and reconfigure urban infrastructures, services, and decision making processes. It is critical that these adaptation plans are developed in a way that is just. Criteria was developed that can be used to assess justice in adaptation so that the processes, priorities, and impacts address the needs of the most vulnerable urban populations. Further, mechanisms are outlined that have been proposed as responsible for producing urban injustice. The justice criteria are applied to the case of adaptation planning in Delhi and the extent to which poor and informal populations are included and affected by this planning. The analysis shows that adaptation planning in Delhi does not meet the justice criteria in part because of a lack of capacity and the political economy of poverty in the city. The criteria for justice and mechanisms of injustice offer an important step toward developing a greater understanding of not only whether city-level adaptation planning is just, but also why it is or is not.
\end{abstract}

Key Words: adaptation; cities and climate change; equity; justice; planning

\section{INTRODUCTION}

Climate change is, and will continue to be, a policy and planning concern for cities around the world. Given the variability in existing capacities, exposures, and development priorities in cities, urban adaptation planning will be a particularly challenging task (de Sherbinin et al. 2007). One important challenge will be ensuring that the processes and outcomes of climate change adaptation are just and that the introduction of adaptation planning does not serve to reinforce or exacerbate existing vulnerabilities in the city (Bulkeley 2010). A first step in achieving this goal is developing clear criteria to use in identifying justice in urban climate change adaptation. In addition, a better understanding of the mechanisms through which policy and planning contribute to urban injustice will help identify entry points for enhancing justice in adaptation.

Criteria for justice in urban climate change adaptation, drawing on classical texts as well as more recent applications related to cities and climate change, contribute to adaptation research and the themes of this special issue. However, it is not enough to simply know whether the adaptation is just; we must also understand why it came to be that way. Four possible mechanisms of injustice are examined: the political economy of poverty, thick injustice, technocratic governance, and institutional capacities, along with the role they may play in urban climate change adaptation. Finally, the case of climate change planning in Delhi is used as an empirical application of the criteria and an examination of the mechanisms of injustice. The criteria, mechanisms, and case study forward our ability to not only evaluate the outcomes of urban climate change adaptation, but also to improve our understanding of why the outcomes occur and how they can be improved. Promoting justice in adaptation is a critical issue for urban residents and communities and one to which the urban politics community can contribute substantial insights.

\section{CITIES AND CLIMATE CHANGE ADAPTATION}

Climate change adaptation can be a direct response to perceived or expected climatic changes, i.e., "clearly identified as being triggered by climate change" (Adger et al. 2005:78), or the result of other, nonclimate related factors such as economic changes. These actions are at times purposefully directed toward addressing climate change and at other times are designed with other, or additional, policy goals in mind (Aall et al. 2007). Adaptation has been defined by the Intergovernmental Panel on Climate Change (IPCC) as "the process of adjustment to actual or expected climate and its effects, in order to moderate harm or exploit beneficial opportunities" (Field et al. 2012:36). Drawn from this definition, those adaptation actions conceived of and implemented by city governments explicitly as a response to climate change are of concern to this research.

Cities face significant adaptation challenges. They are sites of climate change impacts such as floods, heat waves, and heat islands (Grimmond 2007, Gasper et al. 2011). Sea level rise will especially affect coastal cities. For example, in the city of Rio de Janeiro sea level rise is predicted to affect 400,000 people (Young 2011), and coastal flooding is predicted in Dar es Salaam (Kebede and Nicholls 2012). Many inland cities, such as Mexico City, are predicted to experience floods that will be more severe and will inflict greater damage with climate change (Baker 2012). In some cases, ongoing 
urbanization will exacerbate the effects of climate change by increasing temperatures through heat island effects and boosting energy demands (Timmerman and White 1997).

The vulnerability, i.e., the "propensity or predisposition to be adversely affected" (Field et al. 2012:32), of urban populations to the effects of climate change will vary within a given city. People's income and assets are the most consistent indicators of their vulnerability and are used as the two factors characterizing vulnerable and disadvantaged groups. Most disaster-related injuries and deaths in cities occur among lowincome groups (Moser and Satterthwaite 2008, United Nations Habitat 2011). Poverty places populations in a position of greater risk, with fewer resources and options to draw on (Hardoy and Pandiella 2009). Climate change will exacerbate the existing vulnerabilities of the urban poor and create new risks as more areas in a city are exposed to climate related hazards. Inequities in the provision of services and access to resources can hinder the ability of cities to effectively adapt to climate change (Romero Lankao 2010).

Cities around the world are developing plans to adapt to climate change, and these plans will have consequences for the availability and distribution of resources and opportunities. Urban adaptation can result in changes to the built environment, land use patterns, decision making processes, development planning, exposure to hazards, and access to services (Carmin et al. 2009, Ford et al. 2011). For example, cities can incentivize water conservation, fund energy efficient transportation, and improve flood mitigation structures. Although many of these actions intersect with mitigation efforts, e.g., increasing energy-use efficiency, adaptation also requires reducing people's exposure and vulnerability and increasing people's resilience to extreme events (Field et al. 2012). The infrastructure investments required can create spaces of inaccessibility in a city by excluding certain groups and connecting select urban places (Graham and Marvin 2001). Adaptation plans and programs are also likely to be embedded within existing decision making frameworks, priorities, and processes that determine a city's broader socioeconomic development trends. Adaptation, therefore, has the potential to contribute to the reproduction of inequalities and differential environmental burdens in cities and to include or exclude the needs of the most vulnerable, that is, those urban populations that lack wealth and assets.

Adaptation actions should therefore be evaluated, at least in part, based on justice criteria to ensure decision making processes and the distribution of costs and benefits include and benefit urban populations that lack wealth and assets. However, a recent review has shown that our understanding of the consequences of urban climate change governance for justice concerns is lacking (Bulkeley 2010), and most cities do not include justice criteria in their climate change planning efforts (Zeemering 2009, Finn and McCormick 2011). This gap is hindering efforts to improve the environmental performance of cities because "the greatest challenge...is not necessarily the lack of environmental services and infrastructure, but the societal structures reproducing unequal distribution and malfunctioning of these services" (Myllylä and Kuvaja 2005:224).

Previous studies of urban climate change policy have focused on the motivations behind planning processes and their outcomes, primarily in developed countries (Robinson and Gore 2005, Engel and Orbach 2008, Zahran et al. 2008, Amundsen et al. 2010, Ford et al. 2011, Krause 2011, Sharp et al. 2011). Climate change justice research has largely focused on rural areas and resource dependent communities, or conflicts in the global arena (Brown 2003, Adger et al. 2006, Dellink et al. 2009, Füssel 2010, Okereke and Dooley 2010, Marino and Ribot 2012, Yates 2012). The use of participation and collaboration processes in cities, and the political struggles these processes necessarily engage, are only starting to be considered by the IPCC and the broader urban climate change community (Few et al. 2007, van Aalst et al. 2008, Aylett 2010). A more holistic and empirical approach to evaluating justice in urban climate change planning, and, more specifically, plans for adaptation, is a necessary next step.

\section{WHAT IS JUSTICE IN URBAN ADAPTATION?}

Identifying justice in urban adaptation requires clear criteria for evaluating decision making processes and outcomes; at the same time, justice is a contested and normative concept. John Rawls, a prominent political philosopher, saw justice as fairness, meaning that the terms of allocating benefits and burdens are such that a reasonable person would accept them and expect others to do the same (Rawls 1971). He argued that even if all people were given equal liberties and opportunities at birth, differences in position and power would still arise. These social and economic inequalities are just, Rawls claims, only if they work to the greatest benefit of the least-advantaged members of society, what is referred to as the "maximin" criterion (Cohen 1989, Rawls 2001). Rawls' definition is commonly used to evaluate existing institutional arrangements against the ideal system that is able to allocate opportunities and burdens fairly, or what is commonly referred to as a means-based approach to justice.

Nobel Prize winner Amartya Sen later shifted discussions of justice away from Rawls's interest in designing just institutions to an approach that relies on identifying outcomes or options that are more just than the status quo. Sen referred to his approach as "focusing more on the extents of freedoms, rather than on the means" (Sen 1992:xi, emphasis in original), which is often considered an ends-based approach to justice. $\mathrm{He}$ argued that policy options that produce enhanced basic freedoms and opportunities for well-being are more just than the status quo (Sen 2009). Although Sen did not specify what freedoms should be enhanced by these just alternatives, 
Martha Nussbaum proposed the following: life, bodily health, bodily integrity, senses imagination and thought, emotions, practical reason, affiliation, other species, play, and control over one's environment (Nussbaum 2003). This approach to justice is often referred to as the capability approach because "in contrast with the utility-based or resource-based lines of thinking, individual advantage is judged in the capability approach by a person's capability to do things he or she has reason to value" (Sen 2009:231) as the result of a policy or development intervention. Capability, therefore, becomes the metric with which policies, and society more broadly, are judged.

Applying these concepts of justice empirically to urban policy and planning can be difficult, but researchers have found various ways of translating broader concepts of justice, such as those proposed by Rawls and Sen, into evaluative criteria for cities. Some have built on Sen's emphasis on ends-based justice to promote climate change adaptations in cities that benefit vulnerable groups. For example, Moser and Satterthwaite have proposed an asset-based framework for "pro poor adaptation" in which investments in the assets, intellectual and physical, of vulnerable and poor communities are used to reduce vulnerability and improve capacity (Moser and Satterthwaite 2008, 2010, Moser 2011). Hastings (2007) has proposed a "territorial justice" of service provision in which the level of provision always meets the level of need.

However, there is a growing emphasis within the urban environmental justice community to include both meansbased and ends-based justice criteria in evaluations. Although too much emphasis on process and institutions can shift focus away from people's lived experiences, which is Sen's central argument, ignoring these factors "does not permit an assessment of procedural injustice" (Boone 2008:150, emphasis in original) and discounts the "social structure and institutional context that often help determine distributive patterns" (Young 1990:15). Again highlighting the importance of including both means- and ends-based criteria, Jekwu Ikeme (2003) distinguishes justice from equity by defining environmental justice as encompassing both procedural and distributive justice, although equity is often only interested in the distributive outcomes. Agyeman and Evans (2003) argue that the meaningful involvement of all people in decision making and implementation, as well as the equitable distribution of benefits and burdens, are the necessary components of environmental justice in cities, a definition that encompasses both procedural and substantive outcomes. Likewise, Susan Fainstein (2010) has proposed that democracy, diversity, and equity are the basic elements of a just city. Within the climate change justice community, focused at the global scale, there is also an emphasis on both procedural and distributional justice (Adger et al. 2006). Understanding the justice dimensions of both the way in which decisions are made and the outcomes of these decisions therefore becomes a powerful tool for evaluating the justice of a new policy or program, such as adaptation planning.

Despite the growing body of work surrounding urban environmental justice, there is a need to better understand what climate change adaptation in cities will or could mean for vulnerable populations and how to evaluate the process and outcomes of adaptation using justice as a criterion. The growing emphasis on both means- and ends-based, or procedural and distributive, criteria reflects Harvey's description of justice as "a just distribution justly achieved" (Harvey 1973:116). Drawing on this idea, and the work of environmental justice scholars, justice in urban climate change adaptation is defined as 'just adaptation justly achieved.' The criteria for meeting this definition are: (1) inclusiveness, i.e., representation of vulnerable groups in adaptation planning processes for the city; (2) prioritization, i.e., priority setting and framing that recognize the adaptation needs of the vulnerable groups in the city; and (3) impacts, i.e., impacts of adaptation that enhance the freedoms and assets of vulnerable groups in the city (Table 1).

These criteria reflect both the means- and ends-based approaches to evaluating justice and also account for the distinction typically made in evaluations of the effectiveness of public policies between outputs, outcomes, and impacts. Representation of vulnerable groups meets the process criteria for justice and enhances people's ability to affect change in their city through open and democratic decision making processes. Explicit prioritizing of vulnerable groups and framing adaptation as, in part, a tool with which to reduce their vulnerability ensures that planning documents and institutions that develop around adaptation, i.e., outputs and outcomes, reflect equity and fairness concerns. Finally, the tangible results of adaptation planning, i.e., impacts, should meet the criteria of enhancing the freedoms and assets of the city's most vulnerable groups.

\section{THE MECHANISMS OF INJUSTICE}

Although identifying injustice in urban adaptation is important, it is equally important to understand why injustices occur so that strategies for improving the processes and outcomes of urban adaptation are developed. Research in urban politics and planning has shown that there are a variety of mechanisms that have the potential to contribute to continuing injustice in cities. These mechanisms, although not necessarily exclusive or independent, can be categorized as: the political economy of poverty, thick injustice, technocratic governance, and institutional capacities. The extent to which any given mechanism contributes to injustice varies between cities and between policy issues.

\section{Thick injustice}

Contemporary injustices may be the result of past decisions and resource allocations, thus making it difficult to track the 
Table 1. Summary of major contributions to the examination and definition of justice relevant to urban climate change adaptation and proposed criteria for justice in urban adaptation.

\begin{tabular}{|c|c|c|c|}
\hline Author & Topic & Key Argument & Representative Publication \\
\hline John Rawls & Just Institutions & $\begin{array}{l}\text { Justice as fairness: terms of allocating } \\
\text { benefits and burdens are acceptable } \\
\text { to all; inequities work to benefit of } \\
\text { disadvantaged }\end{array}$ & $\begin{array}{l}\text { A Theory of Justice. 1971. Harvard } \\
\text { University Press }\end{array}$ \\
\hline Amartya Sen & Capability Approach & $\begin{array}{l}\text { Outcomes that increase people's } \\
\text { basic capabilities and opportunities } \\
\text { are more just than outcomes that do } \\
\text { not }\end{array}$ & $\begin{array}{l}\text { The Idea of Justice. 2009. Harvard } \\
\text { University Press }\end{array}$ \\
\hline $\begin{array}{l}\text { Catherine Moser and David } \\
\text { Satterthwaite }\end{array}$ & Pro-Poor Adaptation & $\begin{array}{l}\text { Adaptation actions should seek to } \\
\text { increase and rebuild the assets of the } \\
\text { urban poor }\end{array}$ & $\begin{array}{l}\text { Towards Pro-Poor Adaptation to } \\
\text { Climate Change in the Urban Centres } \\
\text { of Low-and Middle-Income } \\
\text { Countries. 2008. IIED Human } \\
\text { Settlements Discussion Paper }\end{array}$ \\
\hline Neil Adger & Climate Change Justice & $\begin{array}{l}\text { Fairness in adaptation responses } \\
\text { requires both procedural and } \\
\text { distributional justice }\end{array}$ & $\begin{array}{l}\text { Fairness in Adaptation to Climate } \\
\text { Change. (with colleagues). 2006. MIT } \\
\text { Press }\end{array}$ \\
\hline Susan Fainstein & Just Cities & $\begin{array}{l}\text { Just cities are democratic, diverse, } \\
\text { and equitable }\end{array}$ & $\begin{array}{l}\text { The Just City. 2010. Cornell } \\
\text { University Press }\end{array}$ \\
\hline $\begin{array}{l}\text { Julian Agyeman; Christopher } \\
\text { Boone }\end{array}$ & Environmental Justice & $\begin{array}{l}\text { Justice requires meaningful } \\
\text { involvement of all people in decision } \\
\text { making and implementation together } \\
\text { with the equitable distribution of } \\
\text { outcomes }\end{array}$ & $\begin{array}{l}\text { Agyeman. "Toward Just } \\
\text { Sustainability in Urban Communities: } \\
\text { Building Equity Rights with } \\
\text { Sustainable Solutions." 2003. Annals } \\
\text { of the American Academy of Political } \\
\text { and Social Science }\end{array}$ \\
\hline Proposed & $\begin{array}{l}\text { Justice in Urban Climate } \\
\text { Change Adaptation }\end{array}$ & \multicolumn{2}{|c|}{$\begin{array}{l}\text { (1) Inclusiveness: representation of vulnerable groups in adaptation planning } \\
\text { processes for the city } \\
\text { (2) Prioritization: priority setting and framing that recognize the adaptation } \\
\text { needs of the vulnerable groups in the city }\end{array}$} \\
\hline
\end{tabular}

source of the injustices to a particular event or institution. This is referred to as thick injustice or "unjust power relations that are deep and densely concentrated, as well as opaque and relatively intractable" (Hayward and Swanstrom 2011:4). Thick injustice is rooted in the historical patterns of a city's governance and infrastructure in a way that makes it difficult to identify and change. From this perspective, injustice in the distribution of burdens and benefits in cities is rooted in historical processes and is a legacy of past policies that continue to affect the participation opportunities, engagement, and outcomes of decisions surrounding land use planning and public services. Past programs for economic restructuring and suburbanization can foster a spatial mismatch between where people can live, where people can work, and their subsequent contemporary access to decision making processes and outcomes (Morello-Frosch 2002). Access to property or green space in the city can be limited for certain racial or ethnic groups because of past decisions that have led to differential housing densities (Heynen et al. 2006).
Thick injustice proposes that injustice is the outcome of historical processes and patterns of allocating resources and access to spaces within the city. This approach has also been called the structural-historical perspective, which is concerned with "the extent to which present-day injustices are the outcome of historical development paths, as opposed to contemporary development policy" (Pelling 2003:168). Pelling (2003) argued that it is important to know the difference if we are to know the degree to which contemporary policy interventions can promote justice. For example, Boone et al. (2009) demonstrated that the current disproportionate exposure of white communities to toxic chemicals in Baltimore was the result of zoning decisions made in the $1920 \mathrm{~s}$ and 1930 s rather than recent decisions made by industry to locate in particular areas.

From a thick injustice perspective, whether or not the outcomes of urban climate change adaptation are just will be determined by past decisions and resource allocations. For 
example, an adaptation strategy centered on enhancing existing flood protection barriers will provide little benefit in areas that don't have flood protection barriers to begin with or whose flood protection barriers have been poorly maintained for the last 50 years. These deeply rooted and place-based inequalities may work to obscure the source of urban injustices and require interventions that are able to rectify the legacy outcomes of past decisions.

\section{Political economy of poverty}

In addition to historical or 'thick' mechanisms of injustice, contemporary political-economic conditions in cities, particularly political representation and access to decision making, have been consistently identified as drivers and maintainers of urban poverty and exclusion. The political economy approach emphasizes the politics of democracy and citizenship in urban decision making processes, and the "rights of the citizen as an urban dweller, or citadin, and user of multiple services " (Lefebvre 1996:34). Although local government is often the most representative scale of government, and this is true in India (Kaviraj 1991), political economy of poverty research has shown that the urban poor are still likely to have fewer opportunities than other groups to influence policy making processes in a meaningful way or help set spending priorities; consequently, the decisions made by municipalities are unlikely to benefit these groups. This dynamic creates a positive feedback loop and a type of poverty trap (Bowles et al. 2006). For example, although in Delhi poorer people are more likely to be politically active, this does not translate into political power because of the prevalence of middle class interests in civil society and newly developed channels of participation and state access that prioritize land ownership (Harriss 2005, Ghertner 2011). As people's access to decision making and investment in the political economy of the city are diminished, so are the benefits they are likely to receive from this system.

In many cases adaptation planning is embedded in existing policy and planning processes (Anguelovski and Carmin 2011), which will further tie adaptation decisions and outcomes to the political economy of urban poverty. Drawing on this approach, we would predict that the inability of vulnerable groups to currently participate in, influence, and be prioritized by the policy process will inhibit just outcomes in urban climate change adaptation. Conversely, from a political economy of poverty perspective, we would expect that cities whose political and institutional arrangements allow for equal access to and influence upon decision making would develop more just adaptation strategies.

\section{Technocratic governance}

Technical information can often be an important input to urban environmental policy and climate change adaptation decisions. A dominance of technical information in policy making can marginalize groups that are not using, familiar with, or included by this information (Fischer 2005, Jasanoff 2007). Particular epistemologies can become institutionalized such that the way information is produced and used results in decisions that do not account for goals or processes that lie outside the dominant way of thinking. For example, Eden and Tunstall (2006) found that ecological restoration projects that rely solely on environmental data and do not account for the needs and motivations of the community are unsuccessful and controversial. Even the tools used to analyze policies, e.g., cost-benefit analyses and efficiency metrics, can lead us to different conclusions about the equity of their distribution of costs and benefits (Hajer and Wagenaar 2003). Government agencies are asked to undertake ever more complex analyses of the risks and benefits of regulation and elite advisory committees are often used as advisers (Jasanoff 1990). The type of information that is used in decision making and the way this information is generated and evaluated can help to determine the accessibility of decision making and its distribution of costs and benefits.

Adaptation is often informed by large-scale climate models and aggregate statistics that underlie temperature and precipitation scenarios for the future. Adaptation, therefore, has the potential to be seen as a purely technical enterprise with justice concerns considerably marginalized (Finn and McCormick 2011). From a technocratic governance perspective, adaptation planning processes that rely heavily on experts and technical information and do not include local knowledge and participation in decision making are less likely to meet the justice criteria. Climate adaptation planning processes should ensure that technical materials are accessible even to those with minimal technical skills and understanding, and more diverse sources of information should be included.

\section{Institutional capacities}

Institutions underlying policy processes can play an important role in determining their outcomes (March and Olsen 1989, Polski and Ostrom 1999). Research has shown that local governmental institutions often lack the administrative, financial, or technical capacity to successfully develop and implement new policies and programs. Because of rapid growth and relatively weak accompanying governance structures, cities in low and middle income countries may particularly lack the qualities of good urban governance: decentralization and autonomy, transparency and accountability, and responsiveness and flexibility (Pelling 2003, Dodman and Satterthwaite 2008, Kraas 2008, Parnell and Walawege 2011). In some cases, a municipality may not have the authority it needs to reach its climate goals because of complex institutional networks and jurisdictions, such as in the case of Mexico City (Romero Lankao 2007). Policy efforts that seek to alleviate urban poverty often have very different approaches and priorities, and any given department is likely to have an incomplete understanding of the problem. Cities may also lack the necessary financial resources caused by an inability to 
generate and collect adequate tax revenue. Municipal governments in highly centralized countries may have limited control over their financial resources. Further, decision makers may lack the technical capacity and training necessary to address the needs of the vulnerable. Cities may lack the institutional capacity to address the needs of vulnerable groups, despite any good intentions.

From this perspective, institutional capacity will play a role in determining whether and to what extent urban climate change adaptation is just. The greater the institutional capacity, e.g., authority, financial resources, and expertise, the more likely a city will be able to develop climate change adaptation strategies that are just.

\section{EMPIRICAL APPLICATION: DELHI}

The city of Delhi is used as a case study for applying the justice criteria and identifying the mechanisms of injustice at play in climate change adaptation planning. Delhi is a useful case for applying the proposed criteria for justice in adaptation planning because it is part of a broader trend: cities in developing and newly industrializing countries taking action on climate change (Betsill and Bulkeley 2007). Although these efforts are still relatively new in Delhi, the city was one of the first major cities in the world to initiate a climate change action plan and is continuing to update its approach to addressing and adapting to climate change. It is a growing city with major deficits in services and a vibrant middle class.

Between April and May 2012, 21 interviews were conducted with people working on climate change issues in the central government, Delhi government, academia, and NGOs. Interviewees were first chosen using a strategic sampling method targeting individuals from government, NGOs, and academia involved in, interested in, or contributing to cityscale planning for climate change, environment, energy, water, or land use. This resulted in an initial set of 15 interviews. A snowball sampling method (Noy 2008) was then used to identify and interview an additional six people that participants thought would be valuable sources of information for the research. The final set of 21 interviews included 8 people from city government, 1 person from subcity government, i.e., the Municipal Corporation of Delhi, 4 people from central government, 6 people from NGOs, and 2 academics.

The interviews were semistructured and included questions on how climate change planning takes place and what it consists of, how vulnerable groups are included, what information was used in the process, and plans for the future (Appendix 1). Because the climate change agenda does not distinguish between mitigation and adaptation aims, participants were asked about climate change actions broadly, and the answers were interpreted and analyzed as they pertained to adaptation. The interviews were transcribed and coded using a deductive coding scheme reflective of the three justice criteria and the four potential mechanisms of injustice. The results from these interviews, together with other literature and government reports, were used to identify the city's climate change challenges, apply the three criteria for justice in adaptation, and determine what mechanisms are at play in producing injustices in adaptation. The analysis, therefore, was largely based on the perceptions and responses of the interviewees as measured against the criteria for justice and potential mechanisms of injustice described in the literature and presented above (Smith and Wiek 2012).

\section{Climate change adaptation and Delhi}

Nearly 17 million people live in the National Capital Territory of Delhi, referred to here as Delhi, and the population has been expanding rapidly, growing by $47 \%$ between 1991 and 2001 and by 20\% from 2001 to 2011 (Census of India 2011). Delhi is predicted to experience increased temperatures and extremes in precipitation in response to climate change (IITM 2005). The city lies on the banks of the Yamuna River, and increases in extreme precipitation events combined with accelerated glacial melt are likely to increase the chance of major floods (Revi 2008). Increased temperatures may also lead to increased urban heat islands, particularly in high density housing neighborhoods. More intense droughts are also predicted for the city and the regions it depends upon for resources. Delhi already struggles to meet the water supply, sanitation, and water quality needs of its residents (Centre for Science and Environment 2012), and climatic changes will exacerbate these challenges.

The city supports a growing middle class that has benefitted greatly, both politically and economically, from globalization and India's subsequent economic growth. The city has also been undergoing significant changes because of its drive to become a world-class, or global, city (Dupont 2011). However, this growth in prominence and wealth has also served to further marginalize the urban poor and working classes (Fernandes 2004, Ghertner 2012). In addition, large portions of the city's residents live in informal settlements that receive little or no city services and are exposed to flooding hazards and air pollution. These groups, the poor and the informal, are the most vulnerable in the city and are the target population for evaluating justice in adaptation in Delhi.

In 2008 the city released its climate change plan, called the Climate Change Agenda for Delhi 2009-2012. The plan contains 65 action points, 1 for every year of India's independence, that include both mitigation and adaptation activities. The plan did not come with explicit budgets but did allocate responsibility for implementation to existing groups and government agencies within the city (former Delhi Department of Environment employee, 30 April 2012, personal communication). These assignments were therefore essentially unfunded and in many cases built on or incorporated existing programs within the agencies. Then in 
August of 2010, the national government initiated a collaborative effort with states to develop a common framework for implementing national climate change objectives. As a union territory, Delhi is currently developing a state level action plan under this framework, which will replace the Climate Change Agenda for Delhi 2009-2012 when it is completed. Funding for the state level action plans is predicted to come from federal ministries as well as from internal, bilateral, multilateral, and private funding sources (United Nations Development Programme (UNDP) representative, 3 May 2012, personal communication). The state action plans are expected to focus more on adaptation and, according to a representative from the national Ministry of Environment and Forests, on 23 May 2012, they hope to get mitigation benefits through adaptation measures and avoid setting explicit emissions targets. Delhi's efforts at climate change adaptation planning are still relatively young: the climate change agenda has only been in place since 2009 and the state level action plan is still being developed. However, Delhi remains one of the early actors in developing a climate change plan, particularly among low and middle income countries, and learning from these experiences can have value not only for the city itself as it moves forward, but also for other cities with similar ambitions.

\section{Justice criterion 1: representation of vulnerable groups in adaptation planning processes}

The planning process for the Climate Change Agenda for Delhi 2009-2012 did not include mechanisms for vulnerable groups to participate or be represented. In 2008, the Chief Secretary of Delhi decided to work on a climate change plan for the city of Delhi beginning with an evaluation of the climate change plans of other global cities, including London. On 8 May 2012, he said: "I started, I must tell you, by searching the net on a number of American cities which have come out with climate change protocols of their own." After drawing on these plans for the conceptual approach, he began collecting data for a plan for Delhi. His methods for collecting data largely followed the central government's methods, "because I saw that that framework would be good for our department too." Finally, he identified 20 government departments in Delhi that should be involved and worked with them to develop 65 action points for the city to tackle between 2009 and 2012. Updates and monitoring took place through weekly conference calls between the Chief Secretary of Delhi and the heads of the government departments.

The process of developing the new state action plan for Delhi may have been more inclusive. This was, in part, because of the involvement of the UNDP who, in collaboration with the central and state governments, helped to develop a common framework for climate change planning at the subnational level in India that included stakeholder workshops. The workshops were intended to target, in part, marginalized communities, civil society, and activists (UNDP representative, 3 May 2012, personal communication). Indeed, a key tenet of the new framework is "that process is important" (UNDP representative, 3 May 2012, personal communication), and indeed partnership and coordination are listed as the first stage of the new framework. However, the framework is voluntary and because Delhi already had a climate change plan in place, it is unclear how closely it will follow the proposed common framework. The Mahatma Gandhi Institute for Combating Climate Change, a quasigovernmental strategic research institute, has been tasked with launching an educational campaign about the Delhi government's targets for the state action plan by targeting communities, NGOs, schools, and colleges. However, there are not similar plans to involve these groups in the construction of the goals themselves.

One way vulnerable groups could be better represented in adaptation planning is through an expansion of the city's Bhagidari System, an initiative of Chief Minister Sheila Dikshit. According to the Chief Minister, she realized there was a need to increase citizen involvement in government beyond voting every few years because "decision making should be participatory all the way through" (Chief Minister Sheila Dikshit, 18 May 2012, personal communication). Bhagidari means 'partnership,' and the program empowers and provides venues for residential welfare associations (RWAs) throughout the city to set priorities for their neighborhood and communicate these to the Delhi government. The Bhagidari System has received international recognition for its innovative approach to metropolitan governance, including a Public Service Award from the United Nations. As mentioned previously, the system currently favors property owners by relying on RWAs, which are themselves "groups of private property owners organized at the neighborhoods level" (Ghertner 2011:505). According to the Chief Minister's office there are 1229 unauthorized colony RWAs that have been provisionally registered with the government (Chief Minister of Delhi, 18 May 2012, personal communication), but these need to be made official if the most vulnerable populations are to be represented. The Bhagidari System has been a conduit for greater public input in the more recent climate change planning process. The leaders of the Bhagidari System have provided input to the state action plan (Chief Minister of Delhi, 18 May 2012, personal communication), and RWAs are seen as important players in implementation (Parks and Gardens Society, 9 May 2012, personal communication). However, despite this progress, there remains no explicit mechanism through which the most vulnerable populations in Delhi can participate specifically in the city's adaptation planning.

Previous research, focused on the procedural or means-based dimensions of justice, has shown that meeting justice criterion 1 requires vulnerable groups to be represented in adaptation planning processes. Based on the evidence presented here, 
Delhi's process does not meet this criterion: decision making about the climate change agenda was highly centralized and lacked transparency, and the current configuration of the Bhagidari System is not inclusive of the city's vulnerable groups. The workshop-based process proposed for the state level action plan and the outreach programs of the Mahatma Gandhi Institute for Combating Climate Change have greater potential to meet this criterion.

\section{Justice criterion 2: priority setting and framing that recognize the adaptation needs of the vulnerable groups in the city}

Evaluating the Climate Change Agenda for Delhi 2009-2012 and the programs and priorities it lays out, i.e., the policy outputs and outcomes, revealed that there were two passages that recognized the needs of vulnerable groups. In the introduction, the agenda reads: "climate change is a global challenge and needs a positive development policy response to ensure that the objectives of growth with equity are achieved while at the same time to ensure long term sustainability of the environment" (GNCTD 2009). However, the agenda does not specify how this is to be achieved, except in the case of water supply, which is the second place where the needs of vulnerable groups are recognized. Overall, the agenda places an emphasis on the need to improve public services and specific objectives are developed for water. The agenda motivates changes in water management by recognizing that current service patterns are inequitable: "Today whether it is the rich or poor all pay the same cost and while the distribution system in rich areas is better and hence the availability, the same is not true of poorer areas of the city" (GNCTD 2009). One way the agenda proposes to remedy this is by providing sewage connections to all villages and unauthorized colonies, a responsibility given to the Delhi Jal Board. This board is using the climate change agenda as a starting point for their own strategic planning and priority setting with a plan set to be released in 2012 (senior official at the Delhi Jal Board, 25 May 2012, personal communication).

Beyond these explicit references, many of the city's adaptation goals are strategically bundled with the city's broader development goals (Aggarwal 2013). For example, when describing the urgency of acting to address climate change, the introduction to the climate change agenda reads, in part: "This means putting in place small efforts which are encapsulated in a framework which makes it possible for each Delhiite to become a part of the process of change. This document sets forth the ways in which Delhi's Development Agenda can be marshaled to meet the objective of preserving our planet" (GNCTD 2009). The aim then seems to be to develop a program that builds on existing development aims. However, the plan does not contain specific strategies by which Delhi's development agenda will be leveraged for climate change benefits, and although there are many components of Delhi's development agenda that target the needs of vulnerable groups, as a whole it does not prioritize the needs of these groups (Ghertner 2010). According to an NGO representative in Delhi: "Currently they are planning for the middle class but climate change requires that they plan for the most poor, the people who are vulnerable. The people who they are planning for, they are more resilient. They are not vulnerable. The communities, the poor communities, are the people who are more vulnerable. But there's no plan that says each person should have access to a minimum number of liters (of water)" (NGO representative in Delhi, 2 May 2012, personal communication).

An important improvement in the forthcoming state action plan is the use of a vulnerability assessment, as recommended in the common framework. The city has commissioned academics from the Indian Institute of Technology to conduct quantitative vulnerability assessments for the city based on potential climate impacts. In theory, the use of a vulnerability assessment should help the city identify and target vulnerable groups. However, it is still not clear how the vulnerability assessment will be conducted and the extent to which it will be used in setting adaptation priorities.

Meeting justice criterion 2 requires that the outputs and outcomes of the policy process recognize and prioritize the adaptation needs of the vulnerable groups in the city. Although vulnerable groups are mentioned in the climate change agenda, particularly in reference to the provision of sewage connections in all villages and unauthorized colonies, the needs of vulnerable groups in Delhi extend well beyond sewage connections. In addition, the climate change agenda is explicitly linked to the broader development goals of Delhi's development agenda, a program that has been criticized for prioritizing the middle class. For these reasons, climate change adaptation planning in Delhi does not meet the second justice criterion.

Justice criterion 3: outcomes and impacts of adaptation
enhance the freedoms and assets of vulnerable groups in
the city Evaluating the outcomes and impacts of the climate change
agenda is challenging for at least two reasons. First, the outcomes and impacts of the climate change agenda are in many ways conflated with the outcomes and impacts of existing programs in the city, such as Delhi's development agenda and the tree planting program of the Parks and Gardens Society, as well as national programs, such as Mission for a Green India and the National Solar Initiative, that have been explicit motivators of some of the targets in the Climate Change Agenda for Delhi 2009-2012. For example, Delhi's tree planting program has successfully partnered with RWAs to revitalize parks and green spaces throughout the city (Parks and Gardens Society, 9 May 2012, personal communication). However, the conflation among the climate change agenda, the existing tree planting program of the Parks and Gardens 
Society, and the national Mission for a Green India makes it difficult to attribute the success of tree planting efforts to the climate change agenda itself.

Second, the city itself has not systematically tracked progress in meeting the goals of the climate change agenda, and many key individuals who were involved with the agenda are now working in very different parts of the government or in the central government. The tracking that has been done largely focused on documenting the introduction of city-level policy measures that are aligned with the six national missions addressed in the climate change agenda, e.g., solar tariffs and mandatory use of CFL light bulbs. Detailed information about where and to what extent these measures have been implemented is not publicly available.

Although attributing outcomes and impacts directly to the climate change agenda is challenging, there is little indirect evidence that the freedoms and assets of vulnerable groups have been enhanced by this program or by the development agenda. Forty-five percent of the city remains unconnected to the sewer network, and $25 \%$ of the city is not connected to the water supply network (senior official at the Delhi Jal Board, 25 May 2012, personal communication). There are ongoing conflicts between the city's river restoration goals, included in the climate change agenda and the development plan, and informal settlements: technically the city is not allowed to relocate people for the purpose of restoration (Delhi Development Authority, 24 May 2012, personal communication), but in some cases court rulings prioritizing Delhi's efforts to become a world-class city have led to the destruction of homes for the purpose of riverbank restoration (Bhan 2009), whereas other projects, such as the Akshardham Temple, have been allowed to take place on the floodplain (Ghertner 2010). The broader environmental agenda has not been conducive to meeting the needs of the most disadvantaged in the city either. Some actions against the interests of the poor and informal in Delhi are the result of public interest litigation brought to the courts by environmentalists, leading to the claim that "bourgeois environmentalism has emerged as an organized force in Delhi" (Baviskar 2003:90).

The perceptions of interviewees mirror these findings. One NGO representative says, "in terms of action...there's nothing unconventional or new being done from the climate change point of view, not much at all" (NGO representative, 2 May 2012 , personal communication). There were no accountability mechanisms in place to ensure that the various departments were implementing their assigned actions. According to a former city government employee, although the departments were asked to report what they were doing, they were never asked why they weren't doing more or completing their tasks (former Delhi Department of Environment employee, 30 April 2012, personal communication). According to this same person, development issues are more important to the city than climate change and so climate change actions are not prioritized. Another NGO representative said "climate change is an add-on in agencies' plans, the city is not serious about it" (NGO representative, 20 May 2012, personal communication) and sees the government's plans to address climate change as a way of placating an increasingly environmentally aware middle class with negative consequences for the poor.

Meeting justice criterion 3 requires that observed impacts of adaptation enhance the freedoms and assets of vulnerable groups in the city. Because of the difficulty of the conflation of the aims and implementation of the climate change agenda with other programs and plans, the fact that the city has not undertaken a targeted assessment of its own, and the lack of evidence that the assets of vulnerable groups in Delhi have significantly increased during this time period, the impacts of adaptation in Delhi do not meet the third justice criterion.

\section{Mechanisms underlying adaptation injustices in Delhi}

The analysis shows that in applying the criteria for justice in adaptation, the process, priorities, and impacts in Delhi do not meet these criteria. Based on the same interview results, there are at least two mechanisms of injustice at play in the city that are contributing to these outcomes: a lack of institutional capacity and the political economy of poverty.

The issue of capacity is evidenced by the shifts in planning process and priorities that have come with the involvement of the UNDP and the development of a common framework for climate change planning at the state level in India. The common framework has introduced the notion of stakeholder workshops, vulnerability assessments, and outreach, all of which have the potential to increase justice in adaptation in Delhi. The Climate Change Agenda for Delhi 2009-2012 was the result of entrepreneurial but isolated work on the part of the Delhi government. With additional resources and guidance from the UNDP and the national government it is the possible to improve the city's capacity to undertake just adaptation planning that includes vulnerable populations in the process, prioritizes their needs, and ultimately enhances their freedoms and assets in ways that reduce their vulnerability.

Additional capacity issues remain, however. Funding for climate change adaptation is extremely limited. There are currently no dedicated funding streams for climate change at the city level. Funding from the national level will depend on the extent to which the state action plan aligns with national priorities. Funding through the Clean Development Mechanism (CDM) tends to favor very large projects that may not address the needs of poor and marginalized communities. There is also a lack of technical capacity in the city. All of the assessment components of the state action plan have been contracted to outside entities, including the vulnerability assessment, emissions inventory, and climate projections and 
scenario development (Local Governments for Sustainability representative, 9 May 2012, personal communication). Finally, there is a lack of institutional capacity. There is no dedicated office for climate change in the city and currently very little invested leadership in developing a robust and just state action plan. Further investment in capacity from within the city will be necessary for just adaptation in Delhi.

A second mechanism of injustice in adaptation for Delhi is the political economy of poverty. The poor and informal populations of the city have very limited venues for accessing decision making, government programs, and public services in Delhi. This is evidenced in part by the provisional status of unauthorized settlements in the Bhagidari System to form RWAs and in the lack of services in these areas because the city is not required to provide water and sanitation to unauthorized colonies (NGO representative, 2 May 2012, personal communication). As the middle class has expanded, poor areas have become increasingly marginalized (Ghertner 2012). According to a representative from an NGO in Delhi, "the government doesn't feel a moral commitment to the poor" because "it is too captivated by the rising power phenomenon" (Delhi NGO representative, 25 May 2012, personal communication). Development goals, then, tend to reflect these ambitions rather than the needs of the most vulnerable groups. In addition, the political dynamics in the city are such that the poor are often marginalized or discounted in decisions about new infrastructure. One NGO representative describes the decision making process surrounding Delhi's metro system built in 2002: "Even for the Metro, the original plan was to go through poor localities to provide public transport. But the real estate mafia re-drew the Metro routes to go through their middle class housing areas and home values went up even higher" (NGO representative, 25 May 2012, personal communication).

If climate change continues to be tied to development goals, it will be subject to the same political economic dynamics. There are signs of this changing. The most recent national fiveyear plan, entitled Faster, Sustainable and More Inclusive Growth, highlights the need to include all Indian citizens in the country's development (representative from the India Planning Commission, 21 May 2012, personal communication). Because state action plans will be tied explicitly to national priorities, this could serve to circumvent city-level mechanisms of injustice.

\section{DISCUSSION AND CONCLUSION}

My aim was to develop criteria that can be used to evaluate whether urban adaptation is just, to identify the mechanisms that may underlie injustice in urban adaptation, and to use these criteria and mechanisms to evaluate the case of Delhi. By reviewing the classic literature on justice as well as more modern urban interpretations, three criteria for justice in urban adaptation were proposed: (1) representation of vulnerable groups in adaptation planning processes for the city, (2) priority setting and framing that recognize the adaptation needs of the vulnerable groups in the city, and (3) outcomes and impacts of adaptation that enhance the freedoms and assets of vulnerable groups in the city. In addition, four potential mechanisms of injustice were identified: the political economy of poverty, thick injustice, technocratic governance, and institutional capacities. These criteria and mechanisms provide a starting point for an urban adaptation research agenda able to more explicitly account for the political forces that underlie decision making about climate change.

Applying these ideas to the case of Delhi showed that the city did not meet the three criteria for justice in urban adaptation. However, the analysis provided insights into how justice may be improved given existing processes and priorities. For example, the Bhagidari System could be further developed for poor populations and informal settlements and could be better integrated into the climate change planning process. The vulnerability assessment that is being conducted as part of the state action plan should be conducted in a way that recognizes the sources of vulnerability people face, should be fully integrated into the planning process, and used for priority setting. Finally, the city should evaluate its progress in meeting its climate change goals. Although coordinating climate change and development goals is useful in many ways, it makes it more difficult to know how well the climate change program itself is doing. Therefore, an additional capacity for the city to develop would-be-tools for tracking and monitoring progress in adapting to climate change is needed.

The analysis also revealed that at least two mechanisms are responsible for the lack of justice in adaptation in Delhi: a lack of capacity and the political economy of poverty. In identifying these mechanisms, we also identified leverage points for change. Efforts to develop the city's capacity further should be a priority. There is already some evidence from the involvement of the UNDP that this can be a successful endeavor. In addition, it will be important to find ways to overcome the political and economic barriers to include vulnerable communities and their needs in climate change adaptation. Such efforts will need to account for the broader development dynamics in the city and the ways that climate change adaptation planning intersects and interacts with current practices and priorities. Although this is perhaps a daunting task, there are already tools in place that could be used as starting points, such as the Bhagidari System.

This special issue examines the governance of climate change adaptation and encourages decision makers and scholars to reflect on the implications of action taken at different levels. Because cities play an increasingly important role in developing and implementing adaptation actions, it is critical that we develop a greater understanding not only of whether urban adaptation is just, but also why it is or is not. Although 
we know that in many cases cities have a poor track record of addressing the needs of the vulnerable, their decision to take on the relatively new policy area of climate change is an opportunity for learning. Research can contribute to this learning by uncovering the mechanisms of injustice in urban climate change adaptation, the obstacles and opportunities for greater justice in different contexts, and, more generally, the relationship between where and how climate planning occurs and the benefits that are experienced.

Future research should expand on these criteria and findings. Are some mechanisms of injustice more prevalent than others in adaptation? How and when do actors overcome barriers to just adaptation? We can also move beyond descriptive explorations of the mechanisms of injustice to examine how, when, and why these mechanisms of injustice are likely to be at play in adaptation. In addition, adaptation planning requires dealing with greater levels of uncertainty and new types of data and information. Future climate scenarios and their impacts are uncertain, particularly at the city scale (Satterthwaite et al. 2007). To what extent does this uncertainty inhibit justice in adaptation planning? The institutional context in which urban climate change adaptation takes place may also help to determine the extent to which the various mechanisms of injustice influence decision making. One unique feature of urban climate change planning is that it is inherently multilevel (Betsill and Bulkeley 2006, Ebi and Semenza 2008, CorfeeMorlot et al. 2009). As a result, the relative authority of municipal, state, and national governments over key planning resources may help determine the extent to which the mechanisms of injustice are able to influence outcomes.

One important requirement for furthering our understanding of justice in urban climate change adaptation is improving our understanding of who the vulnerable and vulnerable groups are in a city, their sources of vulnerability, and the barriers they face to building greater levels of capacity. As my analysis and the Delhi case shows, justice in urban climate change adaptation is fundamentally tied to broader issues of accessibility and participation. Existing research on urban injustice, the right to the city, and urban informality, although not explicitly addressing issues of climate change adaptation, therefore has much to contribute to this understanding. Future investments in climate change policy and planning should focus on leveraging and further developing this type of knowledge in a transparent and inclusive way.

Responses to this article can be read online at: http://www.ecologyandsociety.org/issues/responses. php/5929

\section{Acknowledgments:}

This research was supported by funding from the Advanced Study Program and Integrated Science Program of the National Center for Atmospheric Research and assisted by The Energy and Resources Institute. The author would like to thank Patricia Romero Lankao, Harriet Bulkeley, the editors of this special issue, and two anonymous reviewers for their valuable comments and suggestions. An earlier version of this paper was presented at the 2012 annual meeting of the Association of American Geographers.

\section{LITERATURE CITED}

Aall, C., K. Groven, and G. Lindseth. 2007. The scope of action for local climate policy: the case of Norway. Global Environmental Politics 7(2):83-101.

Adger, W. N., N. W. Arnell, and E. L. Tompkins. 2005. Successful adaptation to climate change across scales. Global Environmental Change 15(2):77-86. http://dx.doi.org/10.1016/ j.gloenvcha.2004.12.005

Adger, W. N., J. Paavola, S. Huq, and M. J. Mace. 2006. Fairness in adaptation to climate change. MIT Press, Cambridge, Massachusetts, USA.

Aggarwal, R. M. 2013. Strategic bundling of development policies with adaptation: an examination of Delhi's climate change action plan. International Journal of Urban and Regional Research 37:1902-15. http://dx.doi.org/10.1111/14$\underline{68-2427.12032}$

Agyeman, J., and T. Evans. 2003. Toward just sustainability in urban communities: building equity rights with sustainable solutions. Annals of the American Academy of Political and Social Science 590(1):35-53. http://dx.doi.org/10.1177/0002$\underline{716203256565}$

Amundsen, H., F. Berglund, and H. Westskog. 2010. Overcoming barriers to climate change adaptation - question of multilevel governance? Environment and Planning C: Government and Policy 28:276-289. http://dx.doi.org/10.1068/ $\underline{\mathrm{c} 0941}$

Anguelovski, I., and J. Carmin. 2011. Something borrowed, everything new: innovation and institutionalization in urban climate governance. Current Opinion in Environmental Sustainability 3(3):169-175. http://dx.doi.org/10.1016/j. cosust.2010.12.017

Aylett, A. 2010. Conflict, collaboration and climate change: participatory democracy and urban environmental struggles in Durban, South Africa. International Journal of Urban and Regional Research 34(3):478-495. http://dx.doi.org/10.1111/ j.1468-2427.2010.00964.x 
Baker, J. L. 2012. Climate change, disaster risk, and the urban poor: cities building resilience for a changing world. World Bank, Washington, D.C., USA.

Baviskar, A. 2003. Between violence and desire: space, power, and identity in the making of metropolitan Delhi. International Social Science Journal 55(175):89-98. http://dx.doi. org/10.1111/1468-2451.5501009

Betsill, M. M., and H. Bulkeley. 2006. Cities and the multilevel governance of global climate change. Global Governance 12 (2):141-159. [online] URL: http://sciencepolicy.colorado. edu/students/envs 4100/betsill 2006.pdf

Betsill, M. M., and H. Bulkeley. 2007. Looking back and thinking ahead: a decade of cities and climate change research. Local Environment 12(5):447-456. http://dx.doi. org/10.1080/13549830701659683

Bhan, G. 2009. "This is no longer the city I once knew". Evictions, the urban poor and the right to the city in millennial Delhi. Environment and Urbanization 21(1):127-142. http:// dx.doi.org/10.1177/0956247809103009

Boone, C. G. 2008. Environmental justice as process and new avenues for research. Environmental Justice 1(3):149-154. http://dx.doi.org/10.1089/env.2008.0530

Boone, C. G., G. L. Buckley, J. M. Grove, and C. Sister. 2009. Parks and people: an environmental justice inquiry in Baltimore, Maryland. Annals of the Association of American Geographers 99(4):767-787. http://dx.doi.org/10.1080/0004$\underline{5600903102949}$

Bowles, S., S. N. Durlauf, and K. Hoff. 2006. Poverty traps. Princeton University Press, Princeton, New Jersey, USA.

Brown, D. A. 2003. The importance of expressly examining global warming policy issues through an ethical prism. Global Environmental Change 13(4):229-234. http://dx.doi.org/10.1016/ S0959-3780(03)00053-0

Bulkeley, H. 2010. Cities and the governing of climate change. Annual Review of Environment and Resources 35:229-253. http://dx.doi.org/10.1146/annurev-environ-072809-101747

Carmin, J., D. Roberts, and I. Anguelovski. 2009. Planning climate resilient cities: early lessons from early adapters. World Bank, 5th urban research symposium, cities and climate change, Marseille, France. World Bank, Washington, D.C., USA.

Census of India. 2011. Provisional population totals: NCT of Delhi. Indian Administrative Service, Delhi, India. [online] URL: http://censusindia.gov.in/2011-prov-results/ prov data products delhi.html

Centre for Science and Environment. 2012. 7th state of India's environment: excreta matters. Centre for Science and Environment, Delhi, India.
Cohen, J. 1989. Democratic equality. Ethics 99(4):727-751. http://dx.doi.org/10.1086/293119

Corfee-Morlot, J., L. Kamal-Chaoui, M. G. Donovan, I. Cochran, A. Robert, and P.-J. Teasdale. 2009. Cities, climate change and multilevel governance. Organisation for Economic Co-operation and Development, Paris, France. http://dx.doi.org/10.1787/220062444715

Dellink, R., M. den Elzen, H. Aiking, E. Bergsma, F. Berkhout, T. Dekker, and J. Gupta. 2009. Sharing the burden of financing adaptation to climate change. Global Environmental Change 19(4):411-421. http://dx.doi.org/10.1016/j.gloenvcha.2009.07.009

de Sherbinin, A., A. Schiller, and A. Pulsipher. 2007. The vulnerability of global cities to climate hazards. Environment and Urbanization 19(1):39-64. http://dx.doi.org/10.1177/09$\underline{56247807076725}$

Dodman, D., and D. Satterthwaite. 2008. Institutional capacity, climate change adaptation and the urban poor. IDS Bulletin 39(4):67-74. http://dx.doi.org/10.1111/j.1759-5436.2008. tb00478.x

Dupont, V. D. N. 2011. The dream of Delhi as a global city. International Journal of Urban and Regional Research. 35 (3):533-554. http://dx.doi.org/10.1111/j.1468-2427.2010.01027. $\underline{x}$

Ebi, K. L., and J. C. Semenza. 2008. Community-based adaptation to the health impacts of climate change. American Journal of Preventive Medicine 35(5):501-507. http://dx.doi. org/10.1016/j.amepre.2008.08.018

Eden, S., and S. Tunstall. 2006. Ecological versus social restoration? How urban river restoration challenges but also fails to challenge the science-policy nexus in the United Kingdom. Environment and Planning C: Government and Policy 24:661-680. http://dx.doi.org/10.1068/c0608j

Engel, K. H., and B. Orbach. 2008. Micro-motives for state and local climate change initiatives. Harvard Law and Policy Review 2:119-137.

Fainstein, S. S. 2010. The just city. Cornell University Press, Ithaca, New York, USA.

Fernandes, L. 2004. The politics of forgetting: class politics, state power and the restructuring of urban space in India. Urban Studies 41(12): 2415-2430. http://dx.doi. org/10.1080/00420980412331297609

Few, R., K. Brown, and E. L. Tompkins. 2007. Public participation and climate change adaptation: avoiding the illusion of inclusion. Climate Policy 7(1):46-59. http://dx.doi. org/10.3763/cpol.2007.0704

Field, C. B., V. Barros, and T. F. Stocker, editors. 2012. Managing the risks of extreme events and disasters to advance climate change adaptation: special report of the 
Intergovrenmental Panel on Climate Change. Cambridge University Press, Cambridge, UK. http://dx.doi.org/10.1017/ CBO9781139177245

Finn, D., and L. McCormick. 2011. Urban climate change plans: how holistic? Local Environment 16(4):397-416. http:// dx.doi.org/10.1080/13549839.2011.579091

Fischer, F. 2005. Citizens, experts, and the environment. Duke University Press, Durham, North Carolina, USA.

Ford, J. D., L. Berrang-Ford, and J. Paterson. 2011. A systematic review of observed climate change adaptation in developed nations. Climatic Change 106(2):327-336. http:// dx.doi.org/10.1007/s10584-011-0045-5

Füssel, H.-M. 2010. How inequitable is the global distribution of responsibility, capability, and vulnerability to climate change: a comprehensive indicator-based assessment. Global Environmental Change 20(4):597-611. http://dx.doi.org/10.1016/ j.gloenvcha.2010.07.009

Gasper, R., A. Blohm, and M. Ruth. 2011. Social and economic impacts of climate change on the urban environment. Current Opinion in Environmental Sustainability 3(3):150-157. http://dx.doi.org/10.1016/j.cosust.2010.12.009

Ghertner, D. A. 2010. Calculating without numbers: aesthetic governmentality in Delhi's slums. Economy and Society 39 (2):185-217. http://dx.doi.org/10.1080/03085141003620147

Ghertner, D. A. 2011. Gentrifying the state, gentrifying participation: elite governance programs in Delhi. International Journal of Urban and Regional Research 35 (3):504-532. http://dx.doi.org/10.1111/j.1468-2427.2011.01043. $\underline{\mathrm{X}}$

Ghertner, D. A. 2012. Nuisance talk and the propriety of property: middle class discourses of a slum-free Delhi. Antipode 44(4):1161-1187. http://dx.doi.org/10.1111/ j.1467-8330.2011.00956.x

Government of National Capital Territory of Delhi (GNCTD). 2009. Climate change agenda for Delhi 2009-2012. Government of National Capital Territory of Delhi, Delhi, India. [online] URL: http://delhi.gov.in/wps/wcm/connect/ doit_publicity/Information+and+Publicity/Home/Publication/ $\underline{\text { Climate+Change+Agenda+For+Delhi+2009-2012 }}$

Graham, S., and S. Marvin. 2001. Splintering urbanism: networked infrastrcutures, technological mobilities and the urban condition. Routledge, London, UK.

Grimmond, S. 2007. Urbanization and global environmental change: local effects of urban warming. Geographical Journal 173(1):83-88. http://dx.doi.org/10.1111/j.1475-4959.2007.232 3. $\underline{\mathrm{X}}$

Hajer, M. A., and H. Wagenaar. 2003. Deliberative policy analysis: understanding governance in the network society.
Cambridge University Press, Cambridge, UK. http://dx.doi. org/10.1017/CBO9780511490934

Hardoy, J., and G. Pandiella. 2009. Urban poverty and vulnerability to climate change in Latin America. Environment and Urbanization 21(1):203-224. http://dx.doi. org/10.1177/0956247809103019

Harriss, J. 2005. Political participation, representation and the urban poor: findings from research in Delhi. Economic and Political Weekly 40(11):1041-1054.

Harvey, D. 1973. Social justice and the city. Edward Arnold, London, UK.

Hastings, A. 2007. Territorial justice and neighbourhood environmental services: a comparison of provision to deprived and better-off neighbourhoods in the UK. Environment and Planning C: Government and Policy 25:896-917. http://dx. doi.org/10.1068/c0657

Hayward, C. R., and T. Swanstrom, editors. 2011. Justice and the American metropolis. University of Minnesota Press, Minneapolis, Minnesota, USA.

Heynen, N., H. A. Perkins, and P. Roy. 2006. The political ecology of uneven urban green space: the impact of political economy on race and ethnicity in producing environmental inequality in Milwaukee. Urban Affairs Review 42(1):3-25. http://dx.doi.org/10.1177/1078087406290729

Ikeme, J. 2003. Equity, environmental justice and sustainability: incomplete approaches in climate change politics. Global Environmental Change 13(3):195-206. http:// dx.doi.org/10.1016/S0959-3780(03)00047-5

Indian Institute of Tropical Meteorology (IITM). 2005. Climate change scenarios for India. Indian Institute of Tropical Meteorology, Delhi, India. [online] URL: http:// www.indiaenvironmentportal.org.in/files/DEFRA-india-climateRainfall.pdf

Jasanoff, S. 1990. The fifth branch: science advisers as policymakers. Harvard University Press, Cambridge, Massachusetts, USA.

Jasanoff, S. 2007. Designs on nature: science and democracy in Europe and the United States. Princeton University Press, Princeton, New Jersey, USA.

Kaviraj, S. 1991. On state, society and discourse in India. Pages 225-250 in J. Manor, editor. Rethinking third world politics. Longman, London, UK.

Kebede, A. S., and R. J. Nicholls. 2012. Exposure and vulnerability to climate extremes: population and asset exposure to coastal flooding in Dar es Salaam, Tanzania. Regional Environmental Change 12(1):81-94. http://dx.doi. org/10.1007/s10113-011-0239-4 
Kraas, F. 2008. Megacities as global risk areas. Urban Ecology 5:583-596. http://dx.doi.org/10.1007/978-0-387-73412-5 38

Krause, R. M. 2011. Symbolic or substantive policy? Measuring the extent of local commitment to climate protection. Environment and Planning C: Government and Policy 29(1):46-62. http://dx.doi.org/10.1068/c09185

Lefebvre, H. 1996. Writings on cities. Wiley-Blackwell, Hoboken, New Jersey, USA.

March, J. G., and J. P. Olsen. 1989. Rediscovering institutions: the organizational basis of politics. Free Press, New York, New York, USA.

Marino, E., and J. Ribot. 2012. Adding insult to injury: climate change and the inequities of climate intervention. Global Environmental Change 22(2):323-328 http://dx.doi.org/10.1016/ j.gloenvcha.2012.03.001

Morello-Frosch, R. A. 2002. Discrimination and the political economy of environmental inequality. Environment and Planning C: Government and Policy 20:477-496. http://dx. doi.org/10.1068/c03r

Moser, C. 2011. A conceptual and operational framework for pro-poor asset adaptation to urban climate change. Pages 225-254 in Cities and climate change: responding to an urgent agenda. World Bank, Washington, D.C., USA. [online] URL: http://siteresources.worldbank.org/INTURBANDEVELOPMENT/ Resources/336387-1256566800920/6505269-1268260567624/ Moser.pdf

Moser, C., and D. Satterthwaite. 2008. Towards pro-poor adaptation to climate change in the urban centers of low-and middle-income countries. International Institute for Environment and Development, Global Research Centre, London, UK. [online] URL: http://pubs.iied.org/10564IIED. $\underline{\mathrm{html}}$

Moser, C., and D. Satterthwaite. 2010. Toward pro-poor adaptation to climate change in the urban centers of low- and middle-income countries. Pages 231-258 in R. Mearns and A. Norton, editors. Social dimensions of climate change: equity and vulnerability in a warming world. World Bank, Washington, D.C., USA.

Myllylä, S., and K. Kuvaja. 2005. Societal premises for sustainable development in large southern cities. Global Environmental Change 15(3):224-237. http://dx.doi.org/10.1016/ j.gloenvcha.2005.01.001

Noy, C. 2008. Sampling knowledge: the hermeneutics of snowball sampling in qualitative research. International Journal of Social Research Methodology 11(4):327-344. http://dx.doi.org/10.1080/13645570701401305

Nussbaum, M. 2003. Capabilities as fundamental entitlements: sen and social justice. Feminist Economics 9 (2-3):33-59. http://dx.doi.org/10.1080/1354570022000077926
Okereke, C., and K. Dooley. 2010. Principles of justice in proposals and policy approaches to avoided deforestation: towards a post-Kyoto climate agreement. Global Environmental Change 20(1):82-95. http://dx.doi.org/10.1016/ j.gloenvcha.2009.08.004

Parnell, S., and R. Walawege. 2011. Sub-Saharan African urbanisation and global environmental change. Global Environmental Change 21:S12-S20. http://dx.doi.org/10.1016/ j.gloenvcha.2011.09.014

Pelling, M. 2003. The vulnerability of cities: natural disasters and social resilience. Earthscan, London, UK.

Polski, M. M., and E. Ostrom. 1999. An institutional framework for policy analysis and design. Workshop in Political Theory and Policy Analysis, Bloomington, Indiana, USA. [online] URL: http://mason.gmu.edu/ mpolski/ documents/PolskiOstromIAD.pdf

Rawls, J. 1971. A theory of justice. Harvard University Press, Cambridge, Massachusetts, USA.

Rawls, J. 2001. Justice as fairness: a restatement. Harvard University Press, Cambridge, Massachusetts, USA.

Revi, A. 2008. Climate change risk: an adaptation and mitigation agenda for Indian cities. Environment and Urbanization 20(1):207-229. http://dx.doi.org/10.1177/0956247808089157

Robinson, P. J., and C. D. Gore. 2005. Barriers to Canadian municipal response to climate change. Canadian Journal of Urban Research 14(1):102-121.

Romero Lankao, P. 2007. How do local governments in Mexico City manage global warming? Local Environment 12 (5):519-535. http://dx.doi.org/10.1080/13549830701656887

Romero Lankao, P. 2010. Water in Mexico City: what will climate change bring to its history of water-related hazards and vulnerabilities? Environment and Urbanization 22 (1):157-178. http://dx.doi.org/10.1177/0956247809362636

Satterthwaite, D., S. Huq, M. Pelling, H. Reid, and P. Romero Lankao. 2007. Adapting to climate change in urban areas: the possibilities and constraints in low- and middle-income nations. International Institute for Environment and Development, London, UK. [online] URL: http://pubs.iied. org/pdfs/10549IIED.pdf?

Sen, A. 1992. Inequality reexamined. Harvard University Press, Cambridge, Massachusetts, USA. http://dx.doi. org/10.1093/0198289286.001.0001

Sen, A. 2009. The idea of justice. Harvard University Press, Cambridge, Massachusetts, USA.

Sharp, E. B., D. M. Daley, and M. S. Lynch. 2011. Understanding local adoption and implementation of climate change mitigation policy. Urban Affairs Review 47 (3):433-457. http://dx.doi.org/10.1177/1078087410392348 
Smith, R., and A. Wiek. 2012. Achievements and opportunities in initiating governance for urban sustainability. Environment and Planning C: Government and Policy 30:429-447. http://dx.doi.org/10.1068/c10158

Timmerman, P., and R. White. 1997. Megahydropolis: coastal cities in the context of global environmental change. Global Environmental Change 7(3):205-234. http://dx.doi.org/10.1016/ S0959-3780(97)00009-5

United Nations Habitat. 2011. Cities and climate change: policy directions: global report on human settlements 2011. Earthscan, London, UK.

van Aalst, M. K., T. Cannon, and I. Burton. 2008. Community level adaptation to climate change: the potential role of participatory community risk assessment. Global Environmental Change 18(1):165-179. http://dx.doi.org/10.1016/j.

gloenvcha.2007.06.002

Yates, J. S. 2012. Uneven interventions and the scalar politics of governing livelihood adaptation in rural Nepal. Global Environmental Change 22(2): 537-546. http://dx.doi. org/10.1016/j.gloenvcha.2012.01.007

Young, I. M. 1990. Justice and the politics of difference. Princeton University Press, Princeton, New Jersey, USA.

Young, A. F. 2011. Sea level rise and flood risk in Rio de Janeiro city: challenges of global climate change. UGEC Viewpoints 5:33-37.

Zahran, S., S. D. Brody, A. Vedlitz, H. Grover, and C. Miller 2008. Vulnerability and capacity: explaining local commitment to climate-change policy. Environment and Planning C: Government and Policy 26:544-562. http://dx. doi.org/10.1068/c2g

Zeemering, E. S. 2009. What does sustainability mean to city officials? Urban Affairs Review 45(2):247-273. http://dx.doi. org/10.1177/1078087409337297 